\title{
Judiciary as the last resort to protect children and adolescents: intersectoral actions, investment in human resources, and structuring of services ${ }^{1}$
}

\author{
Lygia Maria Pereira da Silva² \\ Maria das Graças Carvalho Ferriani ${ }^{3}$ \\ Marta Angélica lossi Silva ${ }^{4}$
}

This study aimed to identify the work developed by the Judiciary to prevent sexual violence against children and adolescents within the family. The approach to social representations in a cultural perspective was used. The field study consisted in the 1st and 2nd Court of Crimes against Children and Adolescents, at the State Supreme Court of Pernambuco, Brazil. Participant observation, semi-structured interviews, and focus group with 17 subjects were the techniques for data collection, analyzed through the interpretation of meanings, allowing the identification of the category "The Judiciary as the ultimate level" and the following subcategories: "The public policies to prevent violence" and "The structure and dynamics of Courts". This study allows the visualization of the Judiciary's limitations with regard to the full protection and absolute priority, and that the work along with the victims demands investments in structure and human resources.

Descriptors: Sexual Violence; Child Advocacy; Prevention and Mitigation; Judicial Power.

\footnotetext{
${ }_{1}^{1}$ Paper extracted from Doctoral Dissertation "A prevenção da violência sexual intrafamiliar contra crianças e adolescentes sob a ótica dos membros do Poder Judiciário", presented to Escola de Enfermagem de Ribeirão Preto, Universidade de São Paulo, WHO Collaborating Centre for Nursing Research Development, Brazil.

${ }^{2}$ RN, PhD, Professor, Faculdade de Enfermagem Nossa Senhora das Graças, Universidade de Pernambuco, Brazil.

${ }^{3}$ RN, PhD, Full Professor, Escola de Enfermagem de Ribeirão Preto, Universidade de São Paulo, WHO Collaborating Centre for Nursing Research Development, Brazil.

${ }^{4}$ RN, PhD, Professor, Escola de Enfermagem de Ribeirão Preto, Universidade de São Paulo, WHO Collaborating Centre for Nursing Research Development, Brazil.
}

\footnotetext{
Corresponding Author:

Lygia Maria Pereira da Silva

Universidade de Pernambuco

Rua Arnóbio Marques, 310

Bairro: Santo Amaro

CEP: 50100-130, Recife, PE, Brasil

E-mail: lygiapera@yahoo.com.br
} 


\title{
O Poder Judiciário como última instância de proteção às crianças e aos adolescentes: ações intersetoriais, investimento em recursos humanos e estruturação dos serviços
}

O objetivo deste estudo foi identificar o trabalho desenvolvido pelo Poder Judiciário para prevenir a violência sexual intrafamiliar contra crianças e adolescentes. Recorreu-se à abordagem das representações sociais numa perspectiva cultural. O campo de estudo consistiu na $1^{\mathrm{a}}$ e na $2^{\mathrm{a}}$ Vara dos Crimes contra a Criança e o Adolescente, no Tribunal de Justiça de Pernambuco, Brasil. Observação participante, entrevistas semiestruturadas e grupo focal com 17 sujeitos foram as técnicas para coleta de dados, analisados por meio da interpretação dos sentidos, que possibilitou a identificação da categoria o Judiciário como último patamar e as seguintes subcategorias: As políticas públicas para prevenção da violência e A estrutura e a dinâmica das Varas. Este estudo permitiu visualizar limitações do Poder Judiciário em relação à proteção integral e à prioridade absoluta, visualizando-se, também, que a atuação junto às vítimas demanda investimentos não só estruturais como, ainda, aqueles que dizem respeito aos recursos humanos.

Descritores: Violência Sexual; Defesa da Criança e do Adolescente; Prevenção e Mitigação; Poder Judiciário.

\section{EI Poder Judicial como última instancia de protección a los niños y adolescentes: acciones intersectoriales, inversión en recursos humanos y estructuración de los servicios}

\begin{abstract}
Este estudio objetivó identificar el trabajo desarrollado por el Poder Judicial para prevenir la violencia sexual intrafamiliar contra niños y adolescentes. Se recurrió al abordaje a las representaciones sociales en perspectiva cultural. El campo de estudio fue el Primero y Segundo Tribunal de Crímenes contra Niños y Adolescentes, en el Tribunal de Justicia de Pernambuco, Brasil. Observación participante, entrevistas semi-estructuradas y grupo focal con 17 sujetos fueron las técnicas de recogida de datos, analizados por medio de la interpretación de los sentidos, que posibilitó la identificación de la categoría "El Judiciario como el último recurso" y las siguientes subcategorías: "Las políticas públicas para prevención de la violencia" y "La estructura y dinámica de los Tribunales". Este estudio permite visualizar limitaciones del Poder Judicial con relación a la protección integral y a la prioridad absoluta, y que la actuación junto a las víctimas demanda inversiones estructurales y en los recursos humanos.
\end{abstract}

Descriptores: Violencia Sexual; Defensa del Niño; Prevención y Mitigación; Poder Judicial.

\section{Introduction}

Defined by the $\mathrm{WHO}^{(1)}$ as a situation of "involvement of a child in sexual activity that he or she does not fully understand, is incapable of giving informed consent or for which the child is not ready and can not consent, or that violates the laws and taboos of society", sexual violence against children and adolescents is recognized as a serious public health problem. Sexual violence is related to various aspects damaging to the biopsychosocial health that may be immediate (if they present in the first two years) and long-term (may accompany the victim throughout life) (2). This form of violence causes various health injuries and has a major impact on the growth and development of children and adolescents. Beyond its importance regarding health injuries, sexual violence against children and adolescents constitutes a crime and therefore, should be addressed by the justice system. The Judicial System aims to seek social justice and guarantee the rights of the citizens ${ }^{(3)}$. Among the institutions involved in dealing with this problem, the Judiciary is of fundamental importance, since the legal responsibility implies the allocation of a penalty related to the crime committed, with the regulation of the 
behavior of individuals and society being the primary function of the $\operatorname{law}^{(4)}$. Added to this is the fact that the legal process establishes legal liability and helps sex offenders to assume responsibility, also the sentence given to the offender acts as a form of reparation for the victim(5).

The approach of the phenomenon of intrafamilial sexual violence against children and adolescents by the Judiciary is necessary, however, in general there are difficulties for the realization of justice. For various reasons related to the legal culture, such as the difficulty of obtaining material evidence and witnesses, and the lengthy procedural requirements, the crime of sexual violence is not always punished according to the $\operatorname{law}^{(3,5)}$. When considering the various interfaces of the phenomenon of intrafamilial sexual violence against children and adolescents, the possibility was noted of the approach, from the standpoint of prevention, considering the primary, secondary and tertiary levels. Such an approach from the Judiciary characterizes tertiary prevention(6), which is recommended, because in addition to the referred health injuries, judicial proceedings often promote revictimization ${ }^{(3,7)}$. In order to comprehend such complexity, it is necessary to approach the work process of the members of the Judiciary with a study involving the subjects, from their point of view. Understanding that the people involved in combating intrafamiliar sexual violence tend to develop their own concepts of the subject, the following research problem was proposed: How do the members of the Judiciary represent their work process in the prevention of intrafamilial sexual violence against children and adolescents? From this question, the object of the present study is presented as the prevention of intrafamilial sexual violence against children and adolescents by the Judiciary.

In seeking to better understand this phenomenon, the knowledge of the socially constructed representations of the professionals is considered indispensable and will provide support for the elaboration of preventive strategies for this form of violence. As the premise of the present study, it is believed that in the representations of the subjects there are probably encountered, difficulties in solidifying a work process based on the principles of integral protection and of absolute priority, given the advances and setbacks in the implementation of laws based on these paradigms. To respond to these assumptions, the study aimed to identify and analyze the social representation of the work process performed by members of the Judiciary concerning the prevention of intrafamilial sexual violence against children and adolescents.

\section{Method}

This is a qualitative strategic study directed towards concrete problems and focuses that arise in society, with the aim of shedding light on certain aspects of reality ${ }^{(8)}$. The research field consisted of the $1^{\text {st }}$ and $2^{\text {nd }}$ Specialized Courts for Crimes against Children and Adolescents (CCCAs) of the Capital, in the State Supreme Court of Pernambuco (SSCP), Brazil. The study subjects were judges, assistants, judicial technicians and analysts. Data collection was conducted from August to December 2009, with the approach of the subjects and collection performed on site, using semi-structured interviews and focus groups, and recorded in a field diary. For the data analysis, interpretation of meanings was used, based on the hermeneutic and dialectic concept, focusing on the cultural phenomenon. An attempt was made to approach the proposed hermeneutic-dialectic analysis, from the following principles: "(a) to seek the internal logic of the facts, reports and observations; (b) to place the facts, reports and observations in the context of the actors; (c) to produce a report of the facts in which the actors can recognize themselves, also using inference"(9). In the operationalization of the interpretation, comprehensive reading of the selected material, exploration of the material and development of interpretive synthesis were performed, considering the context of the CCCAs and the confrontation with the empirical data.

This article is from the doctoral thesis, the project of which was approved by the Research Ethics Committee of the USP Ribeirão Preto, College of Nursing. The study followed the ethical principles of research with human subjects, established by the National Health Council, through Resolution 196/96. In order to ensure anonymity and confidentiality, each study subject was assigned a number, being the same in all the techniques used.

\section{Results and Discussion}

\section{Characterization of the subjects}

The study subjects consisted of 17 members of the CCCAs, with 11 females and six males, with work duration in the SSCP of between five months and 15 years. Regarding the position held, one judge, two assistants, one legal clerk, six judicial technicians and seven judicial analysts took part in the study. Five subjects stated that in the undergraduate course (bachelor's degree in law, pedagogy, psychology and social work) sexual violence against children and 
teenagers was covered, while 12 subjects said they had not studied the theme. Furthermore, 11 had attended a course or lecture on sexual violence against children and adolescents, while six had never participated in any activity on the subject.

\section{Construction of the empirical categories}

In this study it was sought to respond to the question of how the members of the Judiciary represent their work process in preventing intrafamilial sexual violence against children and adolescents? The study data allowed the identification of the category "The judiciary is the ultimate level", having as subcategories: "The public policies for the prevention of violence" and "The structure and dynamics of Courts".

\section{The Judiciary is the ultimate level}

The subjects of the study identified the Judiciary as the last step in cases of intrafamilial sexual violence against children and adolescents.

When the people arrive it has already happened, it has passed from suspicion and has already been configured as a criminal case (S 02). The expression ultimate level appeared in the following statement: (...) I really think that we are at the ultimate level (...) (S 01).

By placing the Judiciary as the ultimate level, the representations do not reveal distinction between the diverse views, according to the professional qualifications of the study subjects, showing that however different the individuals are, they share aspects of the formative matrix of the social group of which they participate. Currently, the Judiciary is encountered among the state public services. Society now deals with the duplication of the concept of work that is presented with the parallelism and the opposition of irreconcilable criteria of rationality, corresponding to the roles of "efficient producer" and "effective maintenance"(10). The Judiciary may be seen as a functional group that, in order to serve society, needs to relate to it in a reflexive manner, assuming a culturally external and structural position.

The CCCAs have the jurisdiction to judge crimes committed against children and adolescents and are provided for in Article 145 of the Child and Adolescent Statute (CAS)(11). This law, in Article 150, also created the multidisciplinary teams. With the formation of these teams, the CCCAs no longer had to rely only on the law graduates and those who exercise notarial functions, receiving a new internal configuration. However, the culture of the Judiciary demonstrates a lack of ability to understand society and its conflicts( ${ }^{(7)}$. Considering the legal tradition, it is understood that the task of the teams of the Judiciary, specifically of the CCCAs, relates to new, challenging and disturbing work. In seeking to secure the rights of the victims, responsibilization ends the steps to be followed(12-13), and the judiciary, by acting through the CCCAs, plays a major role. The concern and commitment to respond to the users of the judiciary, the final phase of a painful journey, is perceived in the statements of the subjects:

When you come here it is because the fact has already happened. Then there is an attempt to stop this act from continuing. (S 12). Prevention from the Judiciary is more or less to prevent it from happening again (S 03).

The cessation of the violence is the first gain that an intervention can provide for the victim. Considering that intrafamilial sexual violence may be chronic, lasting months or years and that the severity of the damage, and other aspects, are also related to the duration of the victimization, the interruption is configured in a way to prevent more serious damage ${ }^{(2,5)}$. Responsibilization through a court judgment, considering sexual violence as a crime that should be prevented, demonstrates the Judicial System as a social and moral reference of the concepts of right and wrong. The responsibilization consists of actions that prevent worsening of the damage and avoid the occurrence of new cases, contribute to interrupting violent behavior against children and adolescents, promote reparation for the victim and encourage society to seek legal punishment(14).

\section{Public policies for the prevention of the violence}

The representations of the subjects regarding prevention revealed the understanding that these actions must be accomplished through public policies, with the participation of the Judiciary.

Prevention would be a joint effort of the whole of society, the state, school, family, all of this (...) (S 14) (...) if it is a coordinated action between the Judiciary, the Child Protection Council and perhaps the schools as well, because they have effective participation in the lives of the children, they might act in a coordinated manner to try to prevent these acts of intrafamilial violence. (S 07)

Public policies in Brazil are established as the response of the state to the demands of society, being the manifestation of the public commitment to work in a particular area in the long term. However, the priority given to the more vulnerable population groups has resulted in focused, compensatory and assistentialistic interventions, of a generally limited scope ${ }^{(15)}$. The 
scarcity, inefficiency or the lack of policies for children and adolescents, which deny the absolute priority, appear in the following statement:

The child as a whole is not the priority for those who make the public policies. Among the priorities of the politicians violence against children and adolescents is the least important (...) (S 05)

The CAS establishes absolute priority in the implementation of the rights of children and

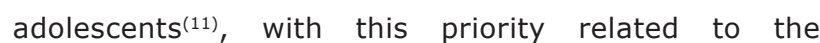
identification of children and adolescents as vulnerable, because they are individuals that are still too immature to meet the demands of the environment, which has been important for the definition of actions that aim for their protection. Unlike the established rights, the scarcity of public policies for children and adolescents can be noted. In the state services, increased financial resources occurs not through the overall increase in resources, but through redistribution, with the budget limit set by a correlation of forces ${ }^{(16)}$. Thus, the arbitrary way that the resources are politically allocated serves interests that are not based on the needs of children and adolescents and does not attend to the imperative of absolute priority. Public funding and the coordination between the sectors, aiming for the performance of integrated actions to address the issue of violence, are provided in the plans and programs for dealing with child and juvenile sexual violence in Brazil, and indicate the crucial role of the Judiciary.

\section{Structure and dynamics of the Courts}

The category structure and dynamics of the Courts refers to the dynamics of the work performed in the quotidian of the members of the CCCAs. Considering that "the work is by definition, human, since it is performed precisely where the technological order is insufficient"(17), the human dimension of its performance is evident, particularly in working with families in situations of intrafamilial violence. However, the functioning of the Judiciary is represented as bureaucratic, detrimental to the priority of the implementation of the rights of the user population. The existing bureaucracy in the Judiciary, the structure of which is based on a technicalbureaucratic model, is compared to an assembly line in a factory, in which an operator continues an activity initiated by another. The judicial structure, by its rules of subordination and bureaucratization, is based on a military model, in which the highest authority is the judge $\mathrm{e}^{(7,12)}$. The complex structure, based on a strong hierarchy, complicates the processing and favors delays, creating advantages for the defendant and characterizing inequality ${ }^{(18-19)}$.

In the Judiciary five, six, ten years pass before a position is taken. It's like "what happened to me did not matter, it was nothing". (S 10) Many cases of sexual crimes reach the limitation period precisely due to lack of application of the penalty in a timely manner. (S 16)

The delay mentioned by various subjects is seen as a way to not do justice, or to do injustice to the victim, according to the following statement:

(...) for the victim, when justice takes too long it is never done. When justice is delayed, it is an injustice. (S 05)

The resolution of a case in legal terms takes at least four years to be completed (18-19), thus constituting a complex, arduous and lengthy course ${ }^{(3,18-19)}$. The delay is attributed, among other causes, to the poor physical structure, to the reduced number of legal clerks and to the way the judges operate, evidencing in some cases a lack of qualification to act on issues of infancy and adolescence. The delay is an indication of inefficiency in the Judiciary, as some processes result in discontinuance or declaration of innocence of the perpetrator of the violence, due to lack of evidence(20). The numbers of the cases in the $1^{\text {st }}$ and the $2^{\text {nd }}$ CCCAs of the State Supreme Court of Pernambuco illustrate the difficulties faced. Between 31/10/2008 and 31/10/2009, 161 of the cases of that period had an outcome: of these cases, 83 received elimination of the possibility of punishment; 14, dismissal of the case; three were acquitted; 11 led to partially successful criminal judgments; and 45 ended in sentences(21). It was observed that the predominant outcomes are those that characterize the lack of effectiveness of the justice, in other words the delay wins, which constitutes an injustice to the victim.

In Article 152 the CAS asserts that "the general rules applicable in the pertinent procedural legislation should also be applied with the procedures regulated in this Law", in its sole paragraph it guarantees "absolute priority in the processing of the cases and procedures provided in this Law, as well as in the implementation of the acts and investigations relating to them"(11). The absolute priority also includes the Judiciary, however, the many years for dealing with cases involving children and adolescents demonstrate the non-fulfillment of that which is provided in law. The subjects recognize the damage caused by the delay, while at the same time affirm the importance of the efficacy of the Judiciary, which was mentioned by several subjects, and celerity is indicated as a means for justice to be done.

(...) one of the key aspects of this prevention policy is to show that these cases are tried quickly, that these cases are 
taken seriously. (S 06) This celerity should really be the main action of the judiciary. (S 08)

The National Justice Council (NJC) ${ }^{(22)}$ developed ten goals aimed at improving the Judiciary. The second of these goals is directed toward celerity and, at the same time, recognizes the injustices arising from the delay in the justice. Despite this initiative, the desire to improve the quality of the work in the CCCAs appears to falter in the bureaucracy and in the non-assimilation of the multidisciplinary teams.

When it comes to us [the multidisciplinary team] it is already at that stage of procedural processing. It already went through a secretary. There was no guidance for the family (...) (S 01)

The operation of a Court Specialized in Crimes against Children and Adolescents is analogous to ordinary Criminal Courts, with their similar procedural rituals(11). The way the cases proceed is closely linked to the hierarchy and bureaucracy of the Judiciary, demonstrating that the social actors do not take into account the specific characteristics of the children and the crimes committed(7). The role of the multidisciplinary team is to provide subsidies to the judicial authority in writing, through reports, or orally at hearings, as well as to develop activities of counseling, guidance, referral, prevention, and others(11). Their work involves conducting interviews to collect information from various people at the premises of the Courts and through visits to homes and schools. To investigate the family situation of the victim or the perpetrator, around ten interviews are necessary. The work of the multidisciplinary team adds dimensions not covered by the law and beyond the prosecution of crimes to the Judiciary. This enables the achievement of the principle of humanizing the CAS, which considers children and adolescents in their situation of people in development, comprehending their context and the complexity of this situation(18).

Achieving effectiveness in the work of a specialized Court requires the qualification of its members. It is necessary to comprehend the meaning of production, circulation, maintenance or transformation of knowledge, in the establishment or continuation of the practices of the subjects. This can be observed in the following statement of one subject:

A training course for people who work directly in the process should be something imperative. (S 16)

Data that characterize the subjects of this research show that the majority had several years of professional experience, however, most had no contact with the theme of sexual violence against children and adolescents in the undergraduate courses. Furthermore, several of them had never participated in any ongoing or sporadic learning situation on the theme. The training of human resources is provided in the National Plan to Combat Child and Juvenile Sexual Violence(13) that involves the Judiciary in the target referring to continuing education for appropriate interventions. However, in the Justice System the victim and family are faced with institutions and professionals that are not always prepared for the delicate issues surrounding sexual violence ${ }^{(14,18)}$. It is important that judges are endowed with sensitivity to pass judgment in the area of childhood and adolescence(11), however, their decision may not be fair if the lawyers do not comprehend the systemic dimension of the violence ${ }^{(18)}$.

The quality of the professional working in the services requires an evaluation that has a different characteristic to material production, because it is not possible to assign them an economic value in itself. Uncertainty regarding the volume, type, time, clients, etc. means that both the planning and the evaluation require more appropriate data(17). In this way, considering the complexity of the theme under study, it is understood that "for the judicial context to simultaneously be a decision and transformation, changes must occur both in the formation of the psychologists, as well as in the formation of the legal operators"(23). In other words, the legal clerks must be qualified to achieve full justice and minimized the damage to those who seek it.

Considering the structure and dynamics of the work in the CCCAs, difficulties can be observed in equalizing the demands of the users with the closed and hierarchical way that the Judiciary functions ${ }^{(7,18)}$. The structural difficulties, the dynamics of the work and the imbalance in the relationships between the sectors lead to constant frustrations that contribute to stress ${ }^{(17)}$. Different aspects of the structure of the CCCAs are discussed by their members according to the role performed by the subject.

We do not have the basic structure for you to see a person, separate, on their own. The only separate room we have is for the defendants remanded in custody that come from the prison (...). (S 05)

The CCCAs are located in a building with a single entrance, with spaces for waiting, which are benches located in the corridors, close to the rooms of the judges. It can be observed that there are no separate facilities for the victims and the perpetrators or accused, with both often staying in the same space. Recently, the Criminal Procedure Code ${ }^{(11)}$ included the need to protect the victims from an encounter with the defendant on the judicial premises. However, there are frequent reports of situations considered unfavorable to the victim, with 
their exposure to embarrassing situations, such as meeting with the offender in the corridors and waiting rooms in the moments prior to the hearings, and even the hearing of the testimony of the child in front of the accused. Such exposure is characterized as secondary victimization that occurs inside the premises and in the procedures performed by the Judiciary, a body that should protect children from any violation ${ }^{(20)}$.

The structuring of services is included in the National Plan to Combat Child and Juvenile Sexual Violence ${ }^{(13)}$, in the goals related to the attendance. The coverage of cases involves appropriate structuring of the services, in some cases requiring reorganization for this purpose. However, contradiction is identified in the representations, as illustrated in the following statement where the subject considers the material structure and the quantity of human resources adequate, yet realizes the need for investment in changing the mindset of the magistrates, in order to humanize their work.

(...) the court is giving a lot of material assistance (...) The mentality of the magistrates needs to change. We already have enough people, paper, now this human side is lacking. (S 17)

Regarding the material assistance provided by the State Supreme Court to the CCCAs, improvements have been observed, with the gradual replacement of furniture and other old equipment with more up to date technology. Interestingly, of the targets set by the $\mathrm{NJC}$, five of them relate to the acquisition of material and the logistical structure, for the computerization of the judicial units, such as internet access, the implementation of the electronic process and the creation of information systems. Regarding the second aspect addressed by the subject, "the mentality of the magistrates" the knowledge of the complexity of the phenomena has required a different attitude on behalf of the lawyers ${ }^{(16,23)}$, perceiving a break from the model of traditional mentality, identified in a more critical view of the reality and their practice, however, in the same field some resistance to the changes necessary to improve the Judiciary is also observed ${ }^{(20)}$.

The development of the human side implies deeper changes, since, with the judge being the authority to which all members of the Courts are subordinate, the mentality of the magistrates has a significant influence in the work process of the teams. The promotion of justice requires a change in the view of all that make up the Judiciary and above all the magistrates need to deeply immerse themselves into the meaning of role of the CCCAs, which is to judge the crimes committed against children and adolescents, and requires sensitivity and specific training for working in such a specialized Court.
The peculiarities of the CCCAs may limit the comparability of the data from this study. However, in spite of such limits, when considering the difficulties encountered in the Judiciary for the incorporation of the concept of a work process that comprehends the principles of integral protection and of the absolute priority for children and adolescents, it is possible that similar situations occur in other regions of Brazil. It is noteworthy that to know and identify the work process developed by the Judiciary concerning the prevention of intrafamilial sexual violence against children and adolescents, involves assessing and explaining this knowledge which comes from studying and being immersed in a little explored area, this being the legal area.

\section{Final Considerations}

The study identified that the Judiciary constitutes a state public service, marked by power and hierarchy, characteristics which reveal structural limits for the exercise of the role of the CCCAs within the principles stated in the Declaration of the Rights of the Child. With the Judiciary being the ultimate level for children and adolescents who seek justice in cases of crimes committed against these groups, difficulties are observed in the realization of justice, given the inadequacy and inefficiency of the public policies and the difficulties imposed by the structure and functioning of the CCCAs.

To conduct the present study, strategic research was chosen that is oriented towards concrete problems and foci that arise in society. From the findings of the study, it is recommended that the composition of a process of joint and integrated work through the promotion of dialogue and the integration of the members of the CCCAs. It is essential to promote managerial and participatory practices that guide the legal clerks to comprehend the phenomenon of intrafamilial sexual violence, through: a) qualification with courses, seminars, case studies, etc.; b) the discussion of cases/ processes with members of the various teams of the CCCAs, from a multidisciplinary viewpoint; c) technical and psychological supervision for the teams, with the aim of articulating the involvement and subjectivity of the professionals faced with the dilemmas or problems in developing the work, contributing to the discussion of themes and changes in the practices. Furthermore, it is considered urgent to improve the physical structure of the CCCAs, with the construction of separate waiting rooms for victims and the accused.

The results of this study contribute to the advancement of knowledge, in that they present 
a contribution guided by the importance of the resignification of the role in tertiary prevention and of the articulation of different actors and areas that comprise the work of integral and intersectorial attention to this phenomenon. Several areas, such as health, education and social care will have their quotidian action objectified and subsidized, not by empirical practices, but by logic and actions that trigger effective measures to protect children, adolescents and support families in situations of sexual violence.

We understand that the discussion of the problem is not exhausted, on the contrary, further studies are needed to promote the comprehension of the concrete problems and foci, peculiar to the case/processes involving children and adolescents in situations of intrafamilial sexual violence.

\section{References}

1. World Health Organization (WHO). Guidelines for medicolegal care for victims of sexual violence. Geneva; 2003.

2. Widom CS, Czaja SJ, Dutton MA. Childhood victimization and lifetime revictimization. Child Abuse \& Neglect. 2008;32:785-96.

3. Froner JP, Ramires VRR. Escuta de crianças vítimas de abuso sexual no âmbito jurídico: uma revisão crítica da literatura [periódico na internet]. Paidéia. 2008[acesso 20 out 2010]; 18(40). Disponível em: http://www.scielo.br/ scielo.php?script =sci_arttext\&pid=S0103863X20080002 $00005 \&$ Ing $=$ en\&nrm=iso.

4. Foucault M. Vigiar e punir: nascimento da prisão. 37th ed. Petrópolis (RJ): Vozes; 2009.

5. Fürniss T. Abuso sexual da criança: uma abordagem multidisciplinar. Porto Alegre: Artes Médicas; 1993.

6. World Health Organization (WHO). Handbook for the documentation of interpersonal violence prevention programs. Geneva; 2004.

7. Roque EMST, Ferriani MGC. Desvendando a violência doméstica contra crianças e adolescentes sob a ótica dos operadores do direito na comarca de JardinópolisSP.[online] Rev. Latino-Am. Enfermagem. [periódico na Internet] 2002 [acesso 19 abr 2011];10(3):334344. Disponível em: http://www.scielo.br/pdf/rlae/ v10n3/13343.pdf.

8. Minayo MCS. O desafio do conhecimento: pesquisa qualitativa em saúde. 10th ed. São Paulo: Hucitec; 2007. 9. Gomes R. Análise e interpretação de dados de pesquisa qualitativa. In: Minayo CS, organizador. Pesquisa social: teoria, método e criatividade. 26th ed. Petrópolis (RJ): Vozes; 2007. p. 79-108.

10. Offe C. Trabalho \& sociedade: problemas estruturais e perspectivas para o futuro da sociedade do trabalho.
In: Offe C. A crise. Rio de Janeiro: Tempo Brasileiro; 1989. v. 1.

11. VadeMecum. 9 ed. São Paulo: Saraiva; 2010.

12. Roque EMST, Ferriani MGC, Silva MAI. Intrafamily violence and justice [periódico na Internet]. Rev. Latino-Am. Enfermagem. [acesso 18 set 2011] 2008 Oct;16(5):908-14. Disponível em: http://www. scielo.br/scielo.php?script =sci_arttext\&pid=S0104$11692008000500018 \&$ Ing $=$ en.

13. Ministério da Justiça (BR). Plano nacional de enfrentamento da violência sexual infanto-juvenil. Brasília; 2001.

14. Fundo das Nações Unidas para a Infância (UNICEF). Varas especializadas e infância: em defesa dos direitos da criança e do adolescente. Brasília (DF): UNICEF; 2004.

15. Carvalho IMM, Almeida PH. Família e proteção social. São Paulo em Perspectivas [periódico na Internet]. 2003 jun.[acesso 20 out 2010]; 17(2):109-22. Disponível em: http://www.scielo.br/scielo.php?script=sci_arttext\&pid= S010288392003000200012\&lng=en\&nrm=iso.

16. Offe C. Trabalho \& sociedade: problemas estruturais e perspectivas para o futuro da sociedade do trabalho. In: Offe C. Perspectivas. Rio de Janeiro: Tempo Brasileiro; 1991.v. 2.

17. Dejours C. Addendum: da psicopatologia à psicodinâmica do trabalho. In: Dejours C. Da psicopatologia à psicodinâmica do trabalho: estudo de psicopatologia do trabalho. 5th ed. Rio de Janeiro: Fiocruz; 2004.

18. Granjeiro IACL, Costa LF. O estudo psicossocial forense como subsídio para a decisão judicial na situação de abuso sexual. [periódico na Internet]. Psicologia: Teoria Pesqui. [acesso 17 out 2010] jun 2008; 24(2). Disponível em: http://www.scielo.br/scielo.php?script=sci_arttext\&pid= S010237722008000200005\&lng=en\&nrm=iso.

19. Martins CBG, Mello JMHP. Desfecho dos casos de violência contra crianças e adolescentes no poder judiciário. [periódico na Internet]. Acta Paul Enferm. [acesso 14 nov 2011] dez 2009; 22(6):800-7. Disponível em: http:// www.scielo.br/scielo.php?script=sci_arttext\&pid=S010321002009000600012\&lng=en.

20. Sadek MTA. Poder Judiciário: perspectivas de reforma. Opinião Pública. maio 2004; 10(1). [Internet] [acesso18 out 2010] Disponível em: http:// www.scielo.br/scielo.php?script $=$ sci_arttext\&pid $=$ S0104-62762004000100002.

21. Tribunal de Justiça de Pernambuco (BR). Centro da criança e do adolescente em Pernambuco será o maior do país. Recife. [Internet] [acesso 30 abr2009]. Disponível em: http://www.tjpe.gov.br/noticias_ascomsY/ver_ noticias. asp id $=5504$ \&argumento= pernambuco.

22. Conselho Nacional de Justiça (BR). Poder Judiciário nacional terá que cumprir 10 metas até o final do ano. 
Paraná; 2009. [Internet]. [acesso 15 jul 2010] Disponível em: http://www.cnj.jus.br/index.php?view=article\&cat id = 1\%3Anotas\&id=6601\%3Apoderjudiciario-nacionaltera-que-cumprir-10-metas-ate-o-final-doano\&format= pdf\&option $=$ com content\&itemid $=169$.

23. Costa LF, Penso MA, Legnani VN, Sudbrack MFO. As competências da psicologia jurídica na avaliação psicossocial de famílias em conflito [periódico na Internet]. Psicol Soc. [acesso 24 nov 2011] ago 2009; 21(2). Disponível em: http://www. scielo.br/scielo.php?script =sci_arttext\&pid=s0102$1822009000200010 \&$ Ing $=$ en\&nrm $=$ iso. 